\title{
Pengaruh Pemberian Jus Buah Jambu Biji (Psidium Guajava L) Terhadap Kelelahan Otot Anaerob Dan Kadar Glukosa Darah Pada Atlet Sepakbola Remaja Di Salatiga Training Center (STC)
}

\author{
Effect of Giving Guava Fruit Juice (Psidium Guajava L) on Anaerobic Muscle Fatigue and Blood Glucose Levels \\ in Teen Soccer Athletes at Salatiga Training Center (STC)
}

\author{
Rudy Widyasulistya*); Ana Yuliah Rahmawati ; Kun Aristiati
}

\begin{abstract}
Background : One athlete's performance is influenced by the availability of blood glucose during exercise. Carbohydrate drinks can supply energy during training and matches. Giving drinks containing 6-8\% carbohydrates before exercise can help maintain blood glucose levels and delay fatigue in athletes.
\end{abstract}

Objective : To determine the effect of guava fruit juice on blood glucose levels and muscle fatigue on athletes as a result of the Training of Salatiga Training Center (STC).

Method : This type of research is Design Experiment with pre-post test control group design. The number of subjects was 26 soccer athletes aged 15-17 years at the Training Center for Salatiga Training Center (STC) who participated in the study. Research subjects received an intervention giving $250 \mathrm{ml}$ of red guava juice and water drink (control). Drinks are given 30 minutes mid-workout. Muscle fatigue using the Running Anaerobic Sprint Test (RAST) method. Blood glucose levels and muscle fatigue are measured before and after exercise. Data were analyzed by paired t-test.

Results : The average initial blood glucose level of the treatment group was $116.84 \mathrm{mg} / \mathrm{dl}$ and the control group was $122.34 \mathrm{mg} / \mathrm{dl}$. The average blood glucose level at the end of the treatment group was $111.46 \mathrm{mg} / \mathrm{dl}$ and the control group $99.53 \mathrm{mg} / \mathrm{dl}$. The decrease in blood glucose levels was greater in the control group by 22.84 $\mathrm{mg} / \mathrm{dl}$ while the treatment group was only $5.38 \mathrm{mg} / \mathrm{dl}$. The average initial muscle fatigue of the treatment group was 2.57 watts / sec and the control group was 2.46 watts / sec. The average end muscle fatigue in the treatment group was 2.13 watts / sec and the control group was 2.75 watts / sec. Increased muscle loss was higher in the control group.

Conclusion : Giving red guava juice to athletes during the match can reduce the decrease in blood glucose levels during exercise compared to the control group $(p=0.012)$. There was no difference in giving guava juice to muscle fatigue in the youth soccer athletes of Diklat Salatiga Training Center (STC) $(p=0.26)$.

Keywords : athletes, football, blood glucose levels, Running Anaerobic Sprint Test.

\section{ABSTRAK}

Latar belakang : Performa atlet salah satunya dipengaruhi oleh ketersediaan glukosa darah selama latihan. Minuman yang mengandung karbohidrat dapat menyuplai energi selama latihan maupun pertandingan. Pemberian minuman yang mengandung karbohidrat 6-8\% sebelum latihan dapat membantu mempertahankan kadar glukosa darah dan menunda kelelahan pada atlet.

Tujuan : Mengetahui adanya pengaruh pemberian jus buah jambu biji terhadap kadar glukosa darah dan kelelahan otot pada Atlet sepabola Diklat Salatiga Training Center(STC).

Metode : Jenis penelitian ini yaitu Eksperimen Design dengan rancangan pre-post test control group design. Jumlah subjek 26 atlet sepak bola usia 15-17 tahun di Diklat Salatiga Training Center (STC) yang berpartisipasi dalam penelitian. Subjek penelitian menerima intervensi pemberian jus jambu biji merah dan minuman Air putih (kontrol) sebanyak $250 \mathrm{ml}$. Minuman diberikan 30 menit pertengahan latihan. Kelelahan otot diukur dengan metode Running Anaerobic Sprint Test (RAST). Kadar glukosa darah dan kelelahan otot diukur sebelum dan setelah latihan. Data dianalisis dengan Uji paired t-test.

Hasil : Rata-rata kadar glukosa darah awal kelompok perlakuan sebesar 116,84 mg/dl dan kelompok kontrol $122,34 \mathrm{mg} / \mathrm{dl}$. Rata-rata kadar glukosa darah akhir kelompok perlakuan yaitu $111.46 \mathrm{mg} / \mathrm{dl}$ dan kelompok kontrol $99.53 \mathrm{mg} / \mathrm{dl}$. Penurunan kadar glukosa darah lebih besar pada kelompok kontrol sebesar 22,84 mg/dl 
sedangkan kelompok perlakuan hanya sebesar 5,38 mg/dl. Rata-rata kelelahan otot awal kelompok perlakuan 2,57 watt/sec dan kelompok kontrol 2.46 watt/sec. Rata-rata kelelahan otot akhir pada kelompok perlakuan 2,13 watt/sec dan kelompok kontrol 2,75 watt/sec. Peningkatan kelelahan otot lebih tinggi pada kelompok kontrol.

Kesimpulan : Pemberian jus jambu biji merah pada atlet sebelum latihan dapat memperkecil penurunan kadar glukosa darah selama latihan dibandingkan kelompok kontrol $(p=0,012)$. Tidak ada perbedaan pemberian jus jambu biji terhadap kelelahan otot pada atlet sepakbola remaja Diklat Salatiga Training Center $(S T C)(p=0,26)$.

Kata kunci : Atlet, sepakbola, kadar glukosa darah, Running Anaerobic Sprint Test

\section{PENDAHULUAN}

Kejuaraan sepak bola di Asia maupun dunia belum pernah diraih oleh tim nasional sepak bola Indonesia. Penurunan prestasi sepak bola Indonesia juga terjadi dua periode terakhir pada piala ASEAN Football Federation (AFF) pada tahun $2016{ }^{1}$. Stamina sangat menentukan performa, sehingga berpengaruh terhadap prestasi atlet dalam kejuaraan sepak bola ${ }^{2}$. Problem utama yang sering ditemui atlet yang sedang berlatih keras adalah kelelahan atau ketidakmampuan untuk memulihkan rasa lelah, dari satu latihan ke latihan berikutnya ${ }^{3}$.

Atlet cepat merasa lelah sehingga mempengaruhi daya tahan fisiknya di lapangan. Jika kelelahan terjadi pada atlet terus menerus maka atlet tidak dapat berkonsentrasi dan performa atlet dapat menurun. Indikator penurunan performa ditentukan oleh kemampuan kontraksi otot yang menghasilkan kekuatan otot. Sepakbola adalah olahraga ketahanan karena berlangsung selama 90 menit dan memerlukan asupan karbohidrat, protein, lemak, serat, cairan dan asupan gizi mikro penting untuk menjaga kesehatan, adaptasi latihan dan stamina pemain ${ }^{6}$. Peningkatan performa atlet tergantung pada intensitas latihan, kondisi fisik, jenis latihan, suhu lingkungan dan makanan sebelum latihan ${ }^{7}$.

Karbohidrat di dalam tubuh yang telah terkonversi menjadi glukosa tidak hanya akan berfungsi sebagai sumber energi utama bagi kontraksi otot atau aktifitas fisik tubuh, namun glukosa juga akan berfungsi sebagai sumber energi bagi sistem syaraf pusat termasuk juga untuk kerja otak. Selain itu, karbohidrat yang dikonsumsi juga dapat tersimpan sebagai cadangan energi dalam bentuk glikogen di dalam otot dan hati. Glikogen otot merupakan sumber energi tubuh saat sedang berolahraga sedangkan glikogen hati dapat berfungsi untuk membantu menjaga ketersediaan glukosa di dalam sel darah dan sistem pusat syaraf $^{18}$. Kelelahan otot dikarenakan simpanan glikogen yang turun secara drastis.

Pangan dengan indeks glikemik rendah akan menurunkan laju penyerapan gula darah dan menekan sekresi hormon insulin pankreas sehingga tidak terjadi kenaikan kadar gula darah. Oleh karena itu, mengkonsumsi pangan indeks glikemik rendah sebelum pertandingan dan latihan merupakan strategi yang baik untuk mempertahankan kadar glukosa darah pada atlet sepakbola ${ }^{12}$.

Buah jambu biji merah merupakan sumber karbohidrat alami dengan indeks glikemik rendah yang dapat dikonsumsi sebagai penyuplai energi selama olahraga Buah jambu biji merah mengandung karbohidrat sebesar $12,2 \mathrm{gr} / 100 \mathrm{gr}$ dan serat sebesar 5,6 gr/100gr buah jambu biji. Menurut Tabel Internasional Indeks Glikemik, nilai IG terendah sebesar 19 dijumpai pada buah jambu biji. Buah jambu biji merah mengandung banyak biji sehingga buah jambu biji merah diolah menjadi jus agar mudah saat dikonsumsi ${ }^{13}$.

Berdasarkan data yang didapatkan dari Salatiga Training Centre (STC) berjumlah 40 atlet sepakbola dengan umur 15-17 tahun. Atlet STC tinggal disebuah mess yang berada di Salatiga. Pada tahun 2017 STC hanya memiliki prestasi 2 kali menjuarai turnamen umum dengan masing-masing mendapat juara 2 turnamen yang diadakan tingkat daerah dikarenakan Atlet STC kelelahan pada babak kedua. Penyebab kelelahan salah satunya diduga karena pengaturan makanan dan jenis cairan yang diberikan selama pertandingan belum dapat mengatasi kelelahan otot pada atlet.

Berdasarkan uraian latar belakang di atas, maka peneliti ingin memberikan intervensi kepada atlet sepak bola di Salatiga Training Centre (STC) dengan pemberian jus jambu biji (Psidium Guajava L.) yang berindeks glikemik rendah untuk melihat pengaruhnya terhadap kelelahan otot anaerob dan glukossa darah. Harapan peneliti dengan pemberian indeks glikemik rendah mampu mempertahankan suplai karbohidrat ke otot dan memperlambat penurunan simpanan glikogen otot, sehingga memperlambat timbulnya kelelahan.

\section{METODE}

Jenis penelitian eksperimen dengan menggunakan rancangan penelitian pretestposttest with control group design. Subjek yang 
memenuhi kriteria inklusi dan ekslusi dikelompokkan menjadi 2, yaitu kelompok perlakuan pemberian jus buah jambu biji 65 gram di larutkan dalam air $185 \mathrm{ml}$ dan memiliki kadar karbohidrat $8 \%$ beserta nilai indeks glikemik 12,3. Pemberian jus jambu biji diberikan sebanyak 1 kali.dan kelompok kontrol (air mineral $250 \mathrm{ml}$ ).

Penelitian dilaksanakan di atlet sepak bola Salatiga Training Center (STC) yang terdiri dari 36 orang dan dilakukan selama 3 hari ( 7 juni - 9 juni 2018 ). Subjek dalam penelitian ini adalah atlet sepak bola laki-laki yang berusia 15-17 tahun. Perhitungan subjek menggunakan rumus lemeshow. Jumlah seluruh subjek penelitian yaitu 36 orang dengan masing-masing 13 orang pada tiap kelompok.

Kelompok perlakuan dalam penelitian ini diberikan jus buah jambu biji 65 gram di larutkan dalam air $185 \mathrm{ml}$ dikonsumsi sebagai minuman selama latihan, sedangkan kelompok kontrol diberikan air mineral $250 \mathrm{ml}$. Variabel dependent yaitu kadar glukosa darah sewaktu subjek yang diukur pada awal dan akhir intervensi dan kelelelahan otot, sedangkan variabel independent yaitu pemberian jus jambu biji.

Instrumen yang digunakan terdiri dari formulir identitas, formulir informed concent, formulir pengecekan kadar glukosa darah sewaktu, dan formulir recall $1 \times 24$ jam dan formulir asupan cairan 1×24 jam, formulir kelelahan otot. Penentuan status gizi dari hasil pengukuran BB yang diukur menggunakan timbangan digital dan TB yang diukur menggunakan microtoice. Persen lemak tubuh menggunakan BIA (Bioelectric Impedance Analyzer). Data kadar glukosa darah sewaktu diukur menggunakan Glukometer One-Touch Select Simple saat sebelum dan sesudah intervensi, Data kelelahan otot menggunakan perhitungan tes RAST (Running Anaerobik Sprint Test).

Analisis univariat digunakan untuk mengetahui karakteristik subjek penelitian berdasarkan umur, indeks massa tubuh, persen lemak tubuh, asupan cairan dan asupan karbohidrat. Perbedaan selisih kadar glukosa darah sewaktu sebelum dan sesudah diberikan perlakuan dengan uji man whitney dan tingkat kemaknaan $\alpha=0,05$ dan perbedaan selisih kelelahan otot sebelum dan sesudah diberikan perlakuan dengan uji man whitney dan analisis multivariat menggunakan uji regresi linier dengan tingkat kemaknaan $\alpha=0,05$.

\section{HASIL}

\section{Karakteristik Subjek Penelitian}

Subyek yang berpartisipasi dalam penelitian adalah atlet sepakbola diklat Salatiga Training Center (STC) yang masih dalam jenjang pendidikan Sekolah Menengah Atas (SMA), kisaran usia 15 - 17 tahun. Sebagian besar siswanya diasramakan di Mess Diklat Salatiga Training Center dengan pengawasan pelatih. Jumlah seluruh subjek penelitian yaitu 36 orang dengan masing-masing 13 orang pada tiap kelompok.

Tabel 1.Karakteristik subjek penelitian di tiap kelompok

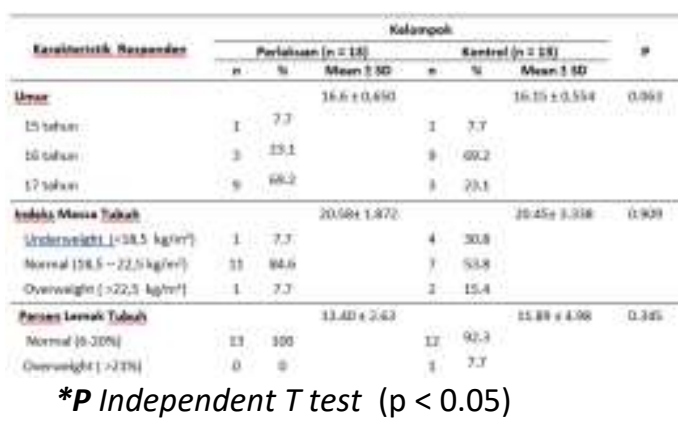

Karakteristik subyek berdasarkan umur atlet pada kelompok perlakuan mayoritas adalah umur 17 tahun (69.2\%), Sedangkan pada kelompok kontrol mayoritas umur 16 tahun (69.2\%). Peningkatan kekuatan otot sebesar 5$10 \%$ terjadi pada usia remaja. Cadangan tenaga dan kekuatan fisik pada usia remaja lebih besar dibanding usia lebih tua. Kekuatan dan massa otot akan menurun seiring dengan pertambahan usia ${ }^{4}$.

Karakteristik subjek menurut status gizi menunjukkan bahwa subjek pada kelompok perlakuan terbanyak memiliki kategori status gizi yaitu normal $(84,6 \%)$, sedangkan rata-rata kelompok kontrol memiliki status gizi normal (53.8\%). Rerata status gizi pada kelompok perlakuan berkisar 20.58 \pm 1.872 dan pada kelompok kontrol berkisar $20.45 \pm 3.338$. Status gizi yang baik diperlukan untuk mempertahankan derajat kebugaran dan kesehatan, membantu pertumbuhan bagi pertumbuhan anak serta menunjang prestasi olahraga $^{32}$.

Karakteristik subjek menurut persen lemak tubuh menunjukkan bahwa subjek pada kelompok perlakuan memiliki kategori normal sebanyak (100\%) dengan rentang (6-20\%) persen lemak tubuh, sedangkan rata-rata kelompok kontrol memiliki persen lemak tubuh sebagian besar normal sebesar (92,3\%). Rerata persen lemak tubuh pada atlet berkisar $13.40 \pm$ 2.63 dan pada kelompok kontrol persen lemak 
tubuh berkisar $11.89 \pm 4.98$. Persen lemak tubuh merupakan salah satu faktor yang dapat membantu atlet bergerak dengan lebih gesit dan lincah. Apabila persentase lemak tubuh seorang atlet berlebih, maka atlet disarankan untuk dapat mengurangi berat badan sehingga dicapai persen lemak tubuh yang ideal ${ }^{4}$.

Pada kedua kelompok perlakuan dan kontrol tidak ada perbedaan didalam hal umur, indeks masa tubuh dan persen lemak tubuh yang ditunjukan dengan $\quad P>0.05$ (0.063, $0.909,0.345)$.

\section{Gambaran Asupan Karbohidrat Dan Asupan Cairan Atlet}

Konsumsi karbohidrat tinggi dalam sehari hari terutama sebelum berolahraga bertujuan untuk meningkatkan simpanan glikogen di dalam tubuh dan untuk menjaga level glukosa di dalam darah sehingga laju produksi energi melalui pembakaran karbohidrat saat berolahraga dapat tetap terjaga, selain asupan karbohidrat diperlukan asupan cairan untuk mempertahankan kelelahan otot atlet agar menjaga tubuh tetap terhidrasi dengan baik melalui pengaturan asupan cairan. Status hidrasi dapat mempengaruhi kebugaran seorang atlet ${ }^{36}$.

Tabel 2. Distribusi gambaran asupan karbohidrat dan asupan cairan pada atlet sepakbola Salatiga Training Center

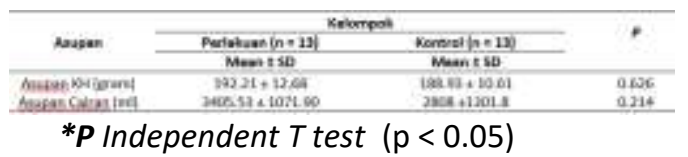

Berdasarkan tabel.2 rata rata asupan karbohidrat pada kelompok perlakuan sebesar 192.21 gram dan pada kelompok kontrol sebesar 188.93 gram. Pada tabel diatas dapat dilihat bahwa nilai $p$ value $=0.626$, maka hasil menunjukkan bahwa tidak terdapat perbedaan antara asupan karbohidrat pada kelompok perlakuan dan kontrol. Hal ini dikarenakan pada atlet sepakbola telah disediakan jadwal dan menu makan setiap harinya dengan jasa catering. Asupan karbohidrat subjek sebelum intervensi untuk masing-masing perlakuan adalah sama. Asupan karbohidrat yang kurang karena pengambilan data bertepatan pada bulan puasa. Pemberian makan pada bulan puasa dilakukan sebanyak 2 kali sehari, pada saat sahur jam 04.00 WIB dan berbuka puasa jam 18.00 WIB. Mayoritas atlet Salatiga Training Center menjalankan puasa ramadhan. Tubuh akan berusaha lebih banyak mengeluarkan cadangan dari lemak dan protein, ketika cadangan karbohidrat rendah. Asupan gizi menjadi unsur yang cukup penting dalam pembinaan sepak bola usia muda, selain berguna untuk mengoptimalkan pertumbuhan juga ditujukan untuk menyiapkan kondisi terbaik atlet baik sebelum, saat dan setelah pertandingan berlangsung. Faktor gizi menjadi bagian science support dalam rangka mewujudkan prestasi sepak bola.

Asupan cairan subjek penelitian didapatkan dengan menggunakan formulir asupan cairan, kemudian di hitung jumlah asupan cairan dalam per hari. Tabel 2 menunjukkan rata rata asupan cairan kelompok perlakuan sebesar $3405.53 \pm 1071.90$ dan rata rata asupan cairann pada kelompok kontrol sebesar 2808 \pm 1301.8 . Tabel menunjukkan bahwa nilai $p$ value $=0.214$, jadi tidak terdapat perbedaan asupan cairan antara kelompok perlakuan dan kelompok kontrol. Pemberian cairan atlet selama bulan puasa yaitu air mineral, teh manis dan minuman jus buah, susu 2 hari sekali.

3. Pengaruh Pemberian Jus Jambu Biji terhadap perubahan Kadar Glukosa Darah Atlet Sepakbola Diklat Salatiga Training Center

Glukosa darah adalah gula yang terdapat didalam darah yang terbentuk dari karbohidrat dalam makanan dan disimpan sebagai glikogen di hati dan otot rangka. Glukosa merupakan sumber energy utama bagi sel manusia. Glukosa dibentuk dari karbohidrat yang dikonsumsi melalui makanan dan disimpan sebagai glikogen dihati dan di otot.

Tabel 3. Hasil kadar glukosa darah sewaktu sebelum dan sesudah intervensi pada atlet sepakbola Diklat Salatiga Training Center

\begin{tabular}{|c|c|c|c|c|c|}
\hline \multirow{3}{*}{$\begin{array}{l}\text { Nedur Glukuses } \\
\text { Darahb }\end{array}$} & \multicolumn{4}{|c|}{ Katements } & \multirow{3}{*}{$p$} \\
\hline & Parlatuen & -131 & Fontroil /n & & \\
\hline & Mean 15D & $\%$ & $\operatorname{Mag} 150$ & $p$ & \\
\hline \multirow{2}{*}{ 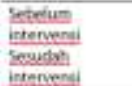 } & $110,3 x \pm 8,49$ & \multirow[b]{2}{*}{0.194} & $122,34 \pm 15,17$ & \multirow[b]{2}{*}{0000} & 0.282 \\
\hline & $11.46 \pm 12,75$ & & $9953 \div 9,35$ & & 0.96 \\
\hline Sollsh & $5.38=1011$ & & $22,84=15,68$ & & 0.012 \\
\hline
\end{tabular}

Pa paired $T$ test perbedaan kadar glukosa darah sebelum dan sesudah perlakuan jus jambu biji, terdapat perbedaan yang bermakna $(p<0.05)$ $\mathrm{Pb}^{\mathrm{b}}$ paired $T$ test perbedaan kadar glukosa darah sebelum dan sesudah intervensi pada kelompok kontrol, terdapat perbedaan yang bermakna $(p<$ 0.05)

P Independent $T$ test kadar glukosa darah sebelum antara kelompok perlakuan jus jambu 
biji dan kelompok kontrol, terdapat perbedaan yang bermakna $(p<0.05)$

PCMan whitney kadar glukosa darah sesudah antara kelompok perlakuan jus jambu biji dan dan kelompok kontrol, terdapat perbedaan yang bermakna $(p<0.05)$

PcMan whitney, perbedaan selisih kadar glukosa darah antara kelompok perlakuan dan kelompok kontrol, terdapat perbedaan yang bermakna $(p<$ 0.05 )

Hasil diatas menunjukkan bahwa terdapat perbedaan yang tidak bermakna antara kadar glukosa darah sebelum dan setelah pemberian intervensi pada perlakuan jus jambu biji $(p=0,194)$, tetapi terdapat perbedaan yang bermakna antara kadar glukosa darah sebelum dan setelah simulasi pertandingan pada kelompok kontrol $(p=0.000)$. Ada penurunan kadar glukosa darah selama pemberian jus jambu biji sebanyak 5,38 $\pm 14,11 \mathrm{mg} / \mathrm{dl}$, sedangkan pada kelompok kontrol penurunan kadar glukosa darah sebesar 22,84 $\pm 15,68$ $\mathrm{mg} /$ dl. Selisih penurunan kadar glukosa darah antara kelompok perlakuan dan kontrol $p$ value $=0,012$ maka menunjukkan bahwa terdapat perbedaan selisih kadar glukosa darah sewaktu antara kelompok perlakuan jus jambu biji dan kelompok kontrol.

Hasil penelitian ini menunjukkan terjadi penurunan kadar glukosa darah selama latihan baik pada kelompok minuman jus jambu biji merah maupun kontrol. Seseorang yang berpuasa atau sedang melakukan aktivitas (latihan olahraga, bekerja) akan menyebabkan turunnya kadar glukosa darah menjadi 60 $\mathrm{mg} / \mathrm{dl}^{26}$. Selama latihan fisik akan terjadi peningkatan penggunakan glikogen otot dan glukosa darah sesuai dengan beratnya aktifitas fisik. Penurunan kadar glukosa darah pada kelompok jus jambu biji merah lebih kecil daripada air putih. Pemberian minuman dengan kandungan karbohidrat $6-8 \%$ selama latihan atau pertandingan dapat mempertahankan konsentrasi glukosa darah sewaktu yang bertujuan agar tidak terjadi hipoglikemi pada saat latihan dan mampu menyediakan sumber energi didalam darah dan mempertahankan cadangan glikogen dalam otot. ${ }^{27}$

Penelitian ini sejalan dengan penelitian Aristanti (2016) yang menunjukkan Penurunan kadar glukosa darah pada kelompok yang diberikan jus jambu biji merah lebih kecil yakni $3.0 \pm 29.4 \mathrm{mg} / \mathrm{dl}$, sedangkan pada perlakuan placebo penurunan kadar glukosa darah sebesar $18.3 \pm 13.0 \mathrm{mg} / \mathrm{dl}$. Menurut statistik, terdapat perbedaan yang bermakna pada kadar glukosa darah dengan kedua jenis kelompok $(p=0.015)$.
Pemberian minuman jus jambu biji merah dapat memperkecil penurunan kadar glukosa darah dibandingkan kelompok placebo.

\section{Pemberian Jus Jambu Biji terhadap Kelelahan Otot Atlet Sepakbola Diklat Salatiga Training Center}

Kelelahan yang dihasilkan oleh aktivitas fisik dianggap sebagai kelelahan yang berasal dari kondisi fisiologis maupun yang berasal dari kondisi psikologis. Kelelahan dapat didefinisikan sebagai berkurangnya kinerja otot dibarengi dengan sensasi rasa lelah. Definisi lain dari kelelahan adalah ketidakmampuan tubuh untuk mempertahankan power output otot ${ }^{8}$.

Tabel 4. Hasil kelelahan otot sebelum dan sesudah intervensi pada atlet sepakbola Diklat Salatiga Training Center

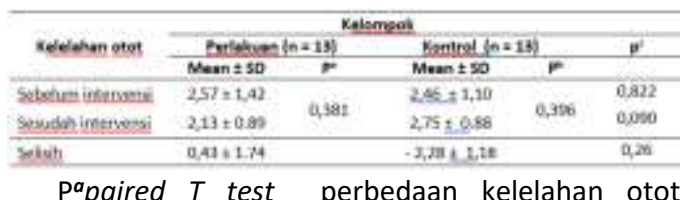
sebelum dan sesudah perlakuan jus jambu biji, terdapat perbedaan yang bermakna $(p<0.05)$

$\mathrm{P}^{b}$ paired $T$ test perbedaan kelelahan otot sebelum dan sesudah pada kelompok kontrol, terdapat perbedaan yang bermakna $(p<0.05)$ $\mathrm{P}$ Independent $T$ test kelelahan otot sebelum antara kelompok perlakuan jus jambu biji dan kelompok kontrol, terdapat perbedaan yang bermakna $(p<0.05)$

$\mathrm{Pc}$ Independent $T$ test kelelahan otot sesudah antara kelompok perlakuan jus jambu biji dan kelompok kontrol, terdapat perbedaan yang bermakna $(p<0.05)$

$\mathrm{P}^{\mathrm{C}}$ man whitney, perbedaan selisih kelelahan otot antara kelompok perlakuan dan kontrol, terdapat perbedaan yang bermakna $(p<0.05)$

Hasil penelitian ini menunjukkan rata rata tingkat kelelahan otot sebelum pemberian intervesi pada atlet berdasarkan perhitungan sebesar 2,57 $\pm 1,42$ dan setelah pemberian intervensi menjadi rata rata $2,13 \pm 0.8$, terjadi penurunan sebesar $0,43 \pm 1.74$ walaupun penurunannya tidak sigifikan.

Kelompok kontrol menunjukkan rata rata tingkat kelelahan otot sesudah pemberian intervesi pada atlet berdasarkan perhitingan sebesar $2.46 \pm 1,10$ dan setelah pemberian intervensi menjadi rata rata $2,75 \pm 0.88$, terjadi peningkatan indeks kelelahan pada kelompok kontrol sebesar $-2,28 \pm 1,18$ walaupun peningkatannya tidak sigifikan. Selisih kelelahan otot antara kelompok perlakuan dan kontrol $p$ 
value $=0,26$, maka menunjukkan bahwa tidak terdapat perbedaan selisih nilai kelelahan otot antara kelompok perlakuan jus jambu biji dan kelompok kontrol. Nilai Anaerobik pada kelompok perlakuan dan kelompok kontrol dapat diartikan semakin rendah nilai Anaerobic Fatigue (AF) maka dapat dikatakan bahwa atlet semakin tidak lelah sehingga bisa meningkatkan performa ketika berolahraga maupun bertanding. Kelelahan otot pada atlet setelah diberikan intervensi menunjukkan atlet dalam range $(0,21-3,21)$ maka termasuk kategori baik. Berbeda dengan kontrol meskipun menurut statistik hasilnya tidak bermakna tetapi terdapat perbedaan nilai kelelahan otot. Kelompok kontrol nilai kelelahannya lebih besar daripada kelompok perlakuan. Hal ini dikarenakan kelelahan otot dipengaruhi oleh kondisi atlet dalam keadaan aktivitas yang ringan karena libur sekolah dan dalam keadaan menjalankan puasa ramadhan. Atlet Salatiga Training Center memiliki jadwal latihan 2 kali sehari dalam keadaan tidak puasa ramadhan dan 1 kali sehari pada saat bulan puasa. Intensitas latihan yang sering atlet mampu mempertahankan fisik secara optimal. Latihan anaerobik merangsang aktivitas otot dalam intensitas tinggi sehingga meningkatkan kekuatan dan daya tahan. ${ }^{39}$ Kelelahan otot dipengaruhi oleh pengosongan ATP-CP, pengosongan simpanan glikogen otot, Akumulasi asam laktat, aktivitas fisik tinggi, penurunan $\mathrm{pH}$ cairan tubuh, penurunan kadar elektrolit cairan tubuh. ${ }^{19}$

5. Analisis faktor yang berpengaruh terhadap kadar glukosa darah sewaktu pada atlet sepakbola Salatiga Training Center (STC)

Analisis multivariate dilakukan untuk menguji faktor faktor (pemberian jus jambu biji, indeks massa tubuh (IMT), persen lemak tubuh, asupan karbohidrat, asupan cairan yang paling berpengaruh terhadap kadar glukosa darah sewaktu pada atlet.

Tabel 7. Analisis multivariat kadar glukosa darah sewaktu

\begin{tabular}{lc}
\hline \multicolumn{1}{c}{ Variabel } & $\begin{array}{c}\text { Kadar dukose darah } \\
\text { terwaktu }\end{array}$ \\
\cline { 2 - 2 } & Pvalue \\
\hline Kelompok periakuan dan kontrol & 0.000 \\
Asupan karbohictrat & 0.111 \\
Asupan cairan & 0.006 \\
Indeks massat tubuh & 0.615 \\
Persen lemak tubuh & 1.000 \\
\hline
\end{tabular}

*Regresi linier $P<0,05$
Berdasarkan hasil penelitian dapat diketahui bahwa hasil kadar glukosa darah antara kelompok perlakuan dan kontrol memiliki nilai $p$ value $=0.00$ yang artinya pada kelompok perlakuan dan kelompok kontrol terdapat selisih kadar glukosa darah yang bermakna karena $\mathrm{p}$ value kurang dari 0.05 . Asupan subyek penelitian dapat dilihat dari asupan cairan subyek yaitu dari hasil penelitian didapatkan asupan cairan menunjukkan $\mathrm{p}$ value $=0.006$ yang artinya asupan cairan berpengaruh terhadap kadar glukosa darah sesudah karena memiliki $p$ value kurang dari $p$ value kurang dari 0,05 sehingga bermakna. Berdasarkan hasil tabel menunjukkan variabel asupan karbohidrat, Indeks Massa Tubuh (IMT) dan persen lemak tubuh tidak berpengaruh terhadap glukosa darah karena nilai $\mathrm{p}$ value lebih dari $0.05(0.111,0.615,1.000)$ sehingga tidak bermakna.

Aktivitas fisik (latihan olahraga, bekerja) akan menyebabkan turunnya kadar glukosa darah menjadi $60 \mathrm{mg} / \mathrm{dl}^{26}$. Selama latihan fisik akan terjadi peningkatan penggunakan glikogen otot dan glukosa darah sesuai dengan beratnya aktifitas fisik. Penurunan kadar glukosa darah pada kelompok jus jambu biji merah lebih kecil daripada air putih.. Pemberian minuman dengan kandungan karbohidrat 6-8\% selama latihan atau pertandingan dapat mempertahankan konsentrasi glukosa darah sewaktu yang bertujuan agar tidak terjadi hipoglikemi pada saat latihan dan mampu menyediakan sumber energi didalam darah dan mempertahankan cadangan glikogen dalam otot. ${ }^{27}$ Salah satu penyebab kelelahan otot yaitu penurunan $\mathrm{pH}$ cairan tubuh dan penurunan kadar elektrolit cairan tubuh. Status hidrasi dapat mempengaruhi kelelahan otot seorang atlet, Jadi mempertahankan pengaturan asupan cairan atlet dapat menjaga tubuh tetap terhidrasi dengan baik. ${ }^{19,36}$

\section{Analisis Faktor Yang Berpengaruh Terhadap Kelelahan Otot Pada Atlet Sepakbola Salatiga Training Center (STC)}

Analisis multivariate dilakukan untuk menguji faktor faktor (pemberian jus jambu biji, indeks massa tubuh (IMT), persen lemak tubuh, asupan karbohidrat, asupan cairan yang paling berpengaruh terhadap kelelahan otot pada atlet.

Tabel 8. Analisis multivariate kelelahan otot 


\begin{tabular}{lc}
\hline \multicolumn{1}{c}{ Variabel } & Kelelahan otot \\
\cline { 2 - 2 } & P value \\
\hline Kelompok perlakuan dan & 0.073 \\
kontrol & \\
Asupan karbohidrat & 0.145 \\
Asupan cairan & 0.708 \\
Indeks massa tubuh & 0.910 \\
Persen lemak tubuh & 0.468 \\
\hline
\end{tabular}

*Regresi linier $P<0,05$

Berdasarkan hasil penelitian dapat diketahui bahwa hasil kelelahan otot antara kelompok perlakuan dan kontrol memiliki nilai $p$ value $=0.073$ yang artinya pada kelompok perlakuan dan kelompok kontrol tidak terdapat perbedaan nilai kelelahan otot yang bermakna karena $\mathrm{p}$ value kurang dari 0.05 .

Hasil tabel menunjukkan variabel asupan karbohidrat, asupan cairan, Indeks Massa Tubuh (IMT) dan persen lemak tubuh tidak berpengaruh terhadap kelelahan otot karena nilai $p$ value lebih dari 0.05 (0.145, 0.708, $0.910,0.468$ ) sehingga tidak bermakna.

Kelelahan otot dipengaruhi oleh kondisi atlet dalam keadaan aktivitas yang ringan dan dalam keadaan menjalankan puasa ramadhan. Atlet Salatiga Training Center memiliki jadwal latihan 2 kali sehari dalam keadaan tidak puasa ramadhan dan 1 kali sehari pada saat bulan puasa. Intensitas latihan yang sering atlet mampu mempertahankan fisik secara optimal. Latihan anaerobik merangsang aktivitas otot dalam intensitas tinggi sehingga meningkatkan kekuatan dan daya tahan. ${ }^{39}$ Pada Kelelahan otot dipengaruhi oleh pengosongan ATP-CP, pengosongan simpanan glikogen otot, Akumulasi asam laktat, aktivitas fisik tinggi, penurunan $\mathrm{pH}$ cairan tubuh, penurunan kadar elektrolit cairan tubuh. ${ }^{19}$

Hal ini tidak sesuai dengan penelitian yang dilakukan Moore et al (2009) membuktikan bahwa terjadi peningkatan performa setelah mengkonsumsi makanan IG rendah dibandingkan setelah mengkonsumsi makanan IG tinggi, serta konsentrasi glukosa darah pada titik kelelahan lebih tinggi secara signifikan setelah mengkonsumsi makanan IG rendah bila dibandingkan setelah mengkonsumsi makanan IG tinggi.

\section{KESIMPULAN}

Pemberian jus jambu biji merah pada atlet pada saat pertandingan dapat memperkecil penurunan kadar glukosa darah selama latihan dibandingkan kelompok kontrol $(p=0,012)$. Tidak ada perbedaan pemberian jus jambu biji terhadap kelelahan otot pada atlet sepakbola remaja Diklat Salatiga Training Center (STC) $(p=0,26)$.

\section{SARAN}

Bagi atlet sepakbola disarankan untuk mengonsumsi jus jambu biji sebanyak $250 \mathrm{ml}$ selama latihan atau dalam pertandingan karena Minuman jus jambu biji merah dengan kadar karbohidrat 6-8\% dapat dijadikan alternatif sebagai minuman karbohidrat untuk menjaga kadar glukosa darah pada atlet selama latihan.

\section{DAFTAR PUSTAKA}

1. Immawati A. Pengaruh Pemberian Sport Drink Terhadap Performa Dan Tes Keterampilan Pada Atlet Sepak Bola Usia 15 - 18 Tahun. 2011;

2. Setiawan MI. Pengaruh Pemberian Jus Semangka Kuning ( Citrulus Lanatus ) Terhadap Konsumsi Oksigen Maksimal ( Vo 2 Max ) Pada Atlet Sepak Bola. 2016;

3. Djuned S. Pengaruh Diet Indeks Glikemik Tinggi Dan Rendah Terhadap Kadar Glukosa Darah Atlet. 2014;

4. Hasanah U. Perbedaan nilai kelelahan anaerobik atlet sepakbola yang diberikan dan tidak diberikan buah semangka (Citrullus lanatus). Artikel. 2015;1-32.

5. Abbasian S, Golzar S, Onvani V, Sargazi L. The predict of RAST Test from WANT test in Elite Athletes. 2012;1(3):72-5.

6. nuasa putra R. Kardiorespirasi Pada Mahasiswa Ukm Dan Non-Ukm Sepakbola Ipb Pernyataan Mengenai Skripsi Dan Sumber Informasi Serta Pelimpahan Hak Cipta *. 2014;

7. Jamurtas $A Z$, Tofas $T$, Fatouros I, Nikolaidis MG, Paschalis V, Yfanti C, et al. The effects of low and high glycemic index foods on exercise performance and beta-endorphin responses. J Int Soc Sports Nutr.2011;8(1):15.

8. Pambudi Istu B. pengaruh pemberiaan makanan indeks glikemik rendah dan tinggi terhadap kelelahan otot pada atlet badminton. 2008;1-5.

9. Welis W. Pengaruh Pemberian Pangan Indeks Glikemik Berbeda Terhadap Stres Oksidatif Dan Peforma Daya Tahan Lari 5KM Pada Atlet Lari. 2012;

10. Yuliana S. Pengaruh pemberian buah indeks 
glikemik rendah terhadap kadar glukosa darah dan daya tahan (endurance) pada atlet renang. 2017;(1992):1-11.

11. Arif A Bin, Budiyanto A. Glicemic Index of Foods and Its Affecting Factors. 2013;32(2).

12. Aristanti A. Pengaruh Pemberian Jus Jambu Biji Merah ( Psidium Guajava L .) Terhadap Kadar Glukosa Darah Pada Atlet Sepakbola Usia 16-18 Tahun. 2016;1-34.

13. International Tables of Glycemic Index and Glycemic Load Values : 2008. 2008;31(12):1820.

14. Istu Pambudi B. Pengaruh Pemberian Makanan Indeks Glikemik Rendah Atau Tinggi Terhadap Kelelahan Otot Atlet Badminton. 2013;43.

15. Nutrients Analysis 2013. 2013;

16. Rimbawan SA. Karbohidrat: indeks glikemik pangan: cara mudah memilih pangan yang menyehatkan. Penebar Swadaya Jakarta. 2004;

17. Wein D. Glycemic Index For Athletes. 2006;6(3):14-5.

18. Training D, Gdtc C, Penelitian A. Pengaruh Pemberian Jus Jeruk Manis (Citrus Sinensis ) Terhadap Nilai Vo 2 Max Atlet Sepak Bola Di Gendut. 2016;

19. Peter J. Training Lactate and Pulse Rate. Oule Finl Polar Electro. 1989;

20. Dorfman L. Nutrition for exercise and sports performance. Mahan LK, Sylvia Escott-Stump" Krause's food, Nutr diet Ther 11th ed Philadelphia Saunders; p508-13. 2012;

21. Sherwood Laurale. Human Physiology From Cells to System. Brooks/Cole Yolanda Cossio, Publiser. 2010;

22. Donaldson CM, Perry TL, Rose MC. Glycemic Index and Endurance Performance. 2010;15465.

23. Hargreaves M, Hawley JA, Jeukendrup A. Preexercise carbohydrate and fat ingestion: effects on metabolism and performance. 2004;31-8.
24. Wright $\mathrm{HH}$. The glycaemic index and sports nutrition. Sajen. 2005;18(3):222-8.

25. Clark. The Athlete's Kitchen. 2001;

26. Utoro BF. Pengaruh Penerapan Carbohydrate Loading Modifikasi Terhadap Kesegaran Jasmani. 2011;

27. Dan P, Terhadap L, Tahan D. Pengaruh Asupan Makan ( Energi , Karbohidrat, Jantung Paru ( Vo 2 Maks ) Atlet Sepak Bola. 2012;

28. Mustamin. Tingkat Pengetahuan Gizi , Asupan Dan Status Gizi Atlet Di Pusdiklat Olahraga Pelajar Sudiang. 2010;|x:47-51.

29. Bryantara, Oktian Firman. Faktor Yang Berhubungan Dengan Kebugaran Jasmani ( Vo2. 2016;(December):237-49.

30. Awisaba RE. Hubungan Antara Status Gizi Dengan Tingkat Kebugaran Jasmani Tim Futsal Putra O2sn Smk Daerah Istimewa Yogyakarta Tahun 2014. 2014;

31. Killpatrick J. Nutrition and diet for high perfomance athletes. Pap Present St Natl Sport Semin Yogyakarta. 1993;

32. Almatsier sunita. 2001. Prinsip Dasar IImu Gizi. Jakarta: Gramedia; 2001.

33. Broker C. Ensiklopedia Keperawatan. EGC Med Publ Karta, 255. 2009;

34. Kuswari, M . Diet glikemik indeks rendah terhadap kadar glukosa darah atlet. 2016.

35. Setyawan CB. Hubungan Antara Konsumsi Cairan Dan Status Hidrasi Pada Siswa Kelas 5 Di Sd N Percobaan 4 Wates. 2017;

36. Rukmana E. Pengaruh Pemberian Minuman Berkarbohidrat Sebelum Latihan terhadap Kadar Glukosa Darah Atlet. E-Journal Undip. 2013;1-22.

37. The I, Sprint RA, Kingdom U. Running-based Anaerobic Sprint Test ( RAST ).

38. Reisma Nirmala Kusumastuti. Pemberian Jus Semangka Terhadap Kelincahan Dan Status Hidrasi Pada Atlet Sepak Bola. Prodi Div Gizi Semarang Poltekkes Kemenkes Semarang. 2017; 